\title{
PENGATURAN LINTAS PENERBANGAN NASIONAL BAGI PESAWAT UDARA ASING DI ATAS ALUR LAUT KEPULAUAN INDONESIA
}

\author{
Levina Yustitianingtyas \\ Fakultas Hukum Universitas Hang Tuah Surabaya \\ Email : levina.yusticia86@gmail.com
}

\begin{abstract}
ABSTRAK
Hukum udara berkaitan dengan kegiatan lintas penerbangan pesawat udara asing utamanya diatur dalam Konvensi Chicago 1944 berikut Annex-annexnya. Hukum udara berkembang melalui praktek negara-negara, atau hasil kesepakatan negara-negara yang dituangkan dalam bentuk perjanjian internasional. Dengan berlakunya United Nations Convention on the Law of the Sea III (UNCLOS III)-1982, terdapat beberapa pasal yang mengatur lintas penerbangan pesawat udara asing melalui rute penerbangan di atas alur laut kepulauan. Beberapa ketentuan dalam UNCLOS-1982 menunjukkan adanya "progresive development" bagi hukum internasional yang berkaitan dengan rejim ruang udara, karena kegiatan lintas penerbangan pesawat udara mendapatkan pengaturan dalam hukum laut. Indonesia adalah salah satu negara kepulauan telah menjadi pihak pada UNCLOS 1982 sejak tahun 1986. Indonesia adalah salah satu Negara pihak pada Konvensi Chicago 1944. Sebagai implementasi dari kedaulatan negara di ruang udara melalui Undang-Undang Nomor 1 Tahun 2009 tentang Penerbangan dan kedaulatan negara Indonesia atas wilayah udara, yang menyatakan bahwa Negara Kesatuan Republik Indonesia berdaulat penuh dan eksklusif atas wilayah udara Republik Indonesia. Status Indonesia sebagai Negara kepulauan sesuai yang tertuang dalam UNCLOS 1982, maka Indonesia mempunyai kewenangan menentapkan alur laut kepulauan dan mengatur pelaksanaan lintas penerbangan pesawat udara asing melalui wilayah udara Negara Indonesia.
\end{abstract}

Kata kunci : lintas penerbangan, wilayah udara, Alur Laut Kepulauan Indonesia.

\begin{abstract}
Air law relating to the activities of foreign airplane crossing is primarily regulated in the Chicago Convention of 1944 and its annexes. Air law develops through the practice of countries, or the results of state agreements as outlined in international agreements. With the enactment of the United Nations Convention on Sea III (UNCLOS III) 1982, there are several articles that regulate the flight of foreign airplanes through flight routes over the archipelagic sea lanes. Some provisions in UNCLOS 1982 show the existence of "progressive development" for international law relating to the airspace regime, because the activities of airplane flight get an arrangement in the law of the sea. Indonesia is one of the archipelagic countries that has been a party to UNCLOS 1982 since 1986. As an implementation of state sovereignty in air space through Law Number 1 of 2009 concerning Aviation and Indonesian state sovereignty over airspace, which states that the Unitary State of the Republic of Indonesia is fully and exclusively sovereign over the territory air of the Republic of Indonesia. The status of Indonesia as an archipelagic country is as set out in UNCLOS 1982, so Indonesia has the authority to determine the archipelagic sea lanes and regulate the implementation of foreign airplane flights through the Indonesian airspace.
\end{abstract}


Keywords: cross flight, airspace, Indonesian archipelagic sea lane passage

\section{Pendahuluan}

Pada bidang kegiatan penerbangan saat ini tidak hanya kegiatan yang bersifat nasional, tetapi juga merupakan kegiatan yang bersifat internasional, oleh karena itu pengaturan kegiatan penerbangan disamping harus mempertimbangkan unsur-unsur batas-batas yurisdiksi suatu negara, juga harus mempertimbangkan unsur-unsur yang sifatnya lintas batas negara. Seiring dengan perkembangan dalam masyarakat internasional saat ini telah melahirkan beberapa konvensi internasional yang mengatur kegiatan penerbangan. Keberadaan hukum udara internasional di dasarkan pada dua prinsip. Pertama, mengakui bahwa tiap negara mempunyai kedaulatan penuh dan mutlak atas wilayah ruang udara, termasuk hak menentukan yurisdiksi atas ruang udara. Kedua, mengakui bahwa wilayah di atas laut bebas adalah sebuah wilayah yang terbuka untuk semua negara dan tidak tunduk pada kekuasaan suatu negara.

Wilayah udara sebagaimana wilayah laut, membawa manfaat bagi kepentingan manusia atau bisa dikatakan untuk negara, yakni sebagai sarana transportasi dan komunikasi (E.Saefullah,1990), media pemersatu, sumber daya nasional, dan media pertahanan dan keamanan nasional. Berdasarkan pada kenyataan yang ada maka sangat diperlukan adanya seperangkat ketentuan hukum, baik dalam tingkat nasional maupun dalam tingkat internasional guna mengatur kegiatan negara di ruang udara.

Semua negara memiliki wilayah udara, namun ada beberapa
Negara yang tidak memiliki wilayah laut. Sampai batas ketinggian berapa negara mempunyai wewenang menjalankan kedaulatannya, hingga dewasa ini belum berhasil ditetapkan atau disepakati oleh Negara-negara. Hal ini berbeda dengan dimensi perairan, yaitu berdasarkan United Nations Convention on the Law of the Sea 1982 (UNCLOS 1982) atau Konvensi Hukum Laut PBB 1982 yang telah berhasil disepakati tentang kedaulatan negara atas wilayah perairannya, serta hak berdaulat negara di bagian-bagian wilayah perairan tertentu.

Berkaitan dengan kedaulatan Negara di udara, pada tahun 1913 muncul dua teori yaitu : a). The Air Freedom Theory menyatakan bahwa udara dapat menjadi bebas karena sifat yang dimilikinya (by its nature is free), dan b). The Air Sovereignty Theory yang menyatakan bahwa ruang udara di atas wilayah suatu negara berada di bawah kedaulatan negara kolong (Priyatna Abdurrasyid, 2003). Terkait dua teori tersebut pada abad-17 hingga abad 19 terdapat dua teori yang saling bertolak belakang tentang status wilayah laut, yaitu teori yang mengatakan bahwa wilayah laut adalah wilayah bebas (mare liberum), dan teori yang mengatakan bahwa wilayah laut adalah sebagai wilayah yang tidak bebas (mare clausum).

Perdebatan tentang status ruang udara di atas wilayah suatu Negara, khususnya berkaitan dengan penggunaan ruang udara tersebut bagi aktifitas penerbangan, akhirnya mendapatkan pengakuan secara internasional sejak dikeluarkannya 
Convention Relating to the Regulation of Aerial Navigation, Signed at Paris, October 13, 1919 (Konvensi Paris 1919) Pasal 1 yang menyatakan bahwa: The High Contracting Parties recognize that every Power has complete and exclusive sovereignty over the air space above its territory, Sedangkan Pasal 1 ayat (2) menggambarkan wilayah udara yang berada di bawah kedaulatan negara,... For the purpose of the present Convention, the territory of a State shall be understood as including the national territory, both that of the mother country and of the colonies, and the territorial waters adjacent thereto. Pada konvensi ini diatur bahwa kedaulatan negara tersebut dibatasi oleh adanya kebebasan lintas damai bagi pesawat udara negara peserta konvensi. Menurut pasal 2 Dalam situasi damai, pesawat udara negara peserta konvensi mempunyai hak lintas damai melalui wilayah ruang udara negara peserta lain Chicago Convention on International Civil Aviation, sifat kedaulatan negara atas wilayah udaranya, berdasarkan Konvensi Paris 1919 tidak mutlak. Kedaulatan negara di ruang udara kembali mendapat pengaturan dalam Chicago Convention on International Civil Aviation, Signed at Chicago, on 7 December 1944 (Konvensi Chicago 1944) Pasal 1 yang menyatakan bahwa: The contracting States recognize that every State has complete and exclusive soveregnty over the airspace above its territory. Pengaturan yang demikian pada dasarnya dimaksudkan untuk mempertegas pengakuan suatu keadaan internasional bahwa sebagian wilayah udara di atas permukaan bumi yang demikian luas ini telah ditetapkan statusnya, yaitu berada di bawah kedaulatan suatu negara. Konsekuensinya, negara kolong dapat melarang masuknya pesawat udara asing dalam wilayah ruang udara suatu negara. Berbeda dengan Konvensi Paris 1919, dalam Konvensi Chicago 1944 bagi setiap pesawat udara asing, apapun jenisnya (Pasal 3, 5 dan 6 Konvensi Chicago 1944), apabila akan memasuki wilayah udara harus mendapatkan izin dari negara kolong. Dengan kata lain di ruang udara suatu negara tidak berlaku hak lintas damai (right of innocent passage) atau tidak ada kebebasan di udara (no freedom of the air) bagi pesawat udara asing lain. Sebagaimana ditegaskan dalam Pasal 3 (c) bahwa: "No state aircraft of a contracting State shall fly over the territory of another State or land thereon without authorization by special agreement or otherwise, and in accordance with the terms thereof'.

Di satu pihak Konvensi Chicago 1944 pada prinsipnya sangat menjunjung tinggi kedaulatan negara, termasuk atas wilayah udaranya. Di pihak lain berkaitan dengan pemanfaatan ruang udara untuk kepentingan bersama masyarakat internasional, konvensi ini juga mengatur sangat rinci aturan-aturan yang terkait dengan penerbangan dan lalu lintas penerbangan di dunia, khususnya penerbangan sipil, demikian juga dalam lampirannya diatur mengenai koordinasi penerbangan militer. Khusus berkaitan dengan jalur-jalur penerbangan, setiap pesawat udara yang akan melintasi wilayah udara harus mematuhi jalur-jalur sebagaimana diatur dalam Enroute Charts ICAO (International Civil Aviation Organization), serta siapa yang diberi kewenangan untuk mengawasi dan mengatur lalu lintas penerbangan di suatu kawasan melalui penetapan flight information region (FIR). 
Indonesia adalah salah satu Negara pihak pada Konvensi Chicago 1944. Sebagai implementasi dari kedaulatan negara di ruang udara melalui Undang-Undang Nomor 15 Tahun 1992 tentang Penerbangan dalam pasal 4 diatur bahwa Negara Republik Indonesia berdaulat penuh dan utuh atas wilayah udara Republik Indonesia. Undang-undang tersebut telah diganti dengan Undang-Undang Nomor 1 Tahun 2009 tentang Penerbangan dan kedaulatan negara Indonesia atas wilayah udara diatur dalam Pasal 5, yang menyatakan bahwa Negara Kesatuan Republik Indonesia berdaulat penuh dan eksklusif atas wilayah udara Republik Indonesia. Wilayah udara yang berada di atas wilayah daratan dan perairan Republik Indonesia merupakan kekayaan nasional, oleh karena itu harus di jaga dan dimanfaatkan bagi sebesar-besar kepentingan rakyat, bangsa, dan Negara.

Sebagai salah satu implmentasi kedaulatan Negara di ruang udara, Konvensi Chicago 1944 melalui Pasal 9 membenarkan dan hal ini merupakan hak dari Negara untuk menetapkan wilayahwilayah yang dinyatakan terlarang untuk penerbangan, baik karena alasan kebutuhan militer maupun keselamatan publik. Dalam beberapa hal, alasan penetapan kawasan udara terlarang adalah untuk kepentingan pertahanan keamanan negara, sepanjang ditetapkan secara wajar dan tidak diskriminatif.

Beberapa hal yang berkaitan dengan hukum udara sekarang ini juga mendapatkan pengaturan dalam hukum laut, yaitu dalam United Nations Convention on the Law of the Sea (UNCLOS- 1982) atau Konvensi Hukum Laut PBB 1982
(KHL-1982). Seperti, kedaulatan negara meliputi ruang udara di atas perairan pedalaman, di atas laut teritotial, dan di atas perairan kepulauan, hal tersebut terdapat dalam Article 2 dan 49 UNCLOS 1982 :.

1. The sovereignty of a coastal State extends, beyond its land territory and internal waters and, in the case of an archipelagic State, its archipelagic waters, to an adjacent belt of sea, described as the territorial sea.

2. This sovereignty extends to the air space over the territorial sea as well as to its bed and subsoil.

Article 49 UNCLOS-1982:

1. The sovereignty of an archipelagic State extends to the waters enclosed by the archipelagic baselines drawn ......

2. This sovereignty extends to the air space over the archipelagic waters,

Adanya hak lintas penerbangan bagi pesawat udara asing melalui wilayah ruang udara negara kepulauan (Article 53 UNCLOS 1982), dan juga adanya hak lintas transit bagi pesawat udara asing melalui ruang udara di atas selat internasional. Dalam article 53 UNCLOS 1982 disebutkan, bahwa lintas penerbangan di atas alur laut kepulauan adalah pelaksanaan hak penerbangan bagi semua pesawat udara. Secara garis besarnya article 53 UNCLOS 1982 dalam kaitannya dengan lintas penerbangan menetapkan hal-hal sebagai berikut:

1. bahwa negara kepulauan dapat menentukan alur laut dan rute penerbangan di atasnya yang cocok digunakan untuk lintas kapal dan pesawat udara asing, semua kapal dan pesawat udara menikmati hak lintas alur laut kepulauan dalam alur laut dan rute penerbangan demikian. Dalam Konvensi Chicago 1944 
jenis pesawat udara di bedakan atas pesawat udara sipil dan pesawat udara negara (termasuk di dalamnya pesawat udara bea-cukai, militer dan polisi). Pasal 3 (a) dan (b). Berdasarkan perumusan Pasal 53 ayat (1) maka semua pesawat mempunyai hak lintas,

2. lintas alur laut kepulauan berarti pelaksanaan hak pelayaran dan penerbangan sesuai dengan ketentuanketentuan Konvensi ini,

3. alur laut dan rute penerbangan yang demikian harus melitnasi perairan kepulauan dan laut teritorial serta meliputi rute lintas normal yang digunakan untuk penerbangan melalui atau rangkaian garis sumbu,

4. Alur laut dan rute penerbangan demikian harus ditentukan dengan suatu rangkaian garis sumbu,

5. Dalam hal negara kepulauan tidak menentukan alur laut atau rute penerbangan, maka hak lintas alur laut kepulauan dapat dilaksanakan melalui rute yang biasanya digunakan untuk pelayaran/ penerbangan internasional.

Berdasarkan Pasal 53 tersebut, dapat disimpulkan bahwa penetapan rute penerbangan kepulauan akan ditentukan di atas alur laut kepulauan. Semua kapal dan pesawat udara asing mempunyai hak untuk melakukan lintas pelayaran dan penerbangan, melintas perairan kepulauan Indonesia melalui alur laut kepulauan dan rute penerbangan di atasnya. Pelayaran dan penerbangan yang demikian dijamin, dalam arti tidak diperlukan izin terlebih dahulu dari Pemerintah Indonesia. UNCLOS 1982 juga mengatur tentang lintas transit melalui selat. Kedua jenis lintas tersebut menunjukkan adanya kemiripan. Regim hukum lintas penerbangan pesawat udara di atas selat internasional, yaitu selat yang digunakan untuk pelayaran internasional antara satu bagian laut lepas atau zona ekonomi eksklusif dan bagian laut lepas atau zona ekonomi eksklusif lainnya (article 37 UNCLOS 1982) adalah lintas transit (transit passage), yaitu pelaksanaan kebebasan penerbangan untuk tujuan transit yang terus menerus, langsung dan secepat mungkin (article 38 par.2 UNCLOS 1982), sedangkan yang dimaksud dengan lintas penerbangan alur laut kepulauan adalah pelaksanaan hak penerbangan semata-mata untuk tujuan transit yang dilakukan secara terus menerus, langsung dan secepat mungkin. Dengan adanya kemiripan ciri-ciri antara lintas penerbangan bagi pesawat udara di atas selat internasional dengan lintas penerbangan melalui alur laut kepulauan, maka berdasarkan article 54 UNCLOS 1982, Pasal-pasal 39, 40, 42 dan 44 berlaku mutatis mutandis bagi lintas (penerbangan) alur laut kepulauan. Namun, bagi selat yang berada di dalam perairan kepulauan, sebagiamana yang terdapat dalam article 38 par. 1 UNCLOS 1982, lintasan bagi kapal berlaku dua kemungkinan rezim hukum yaitu hak lintas damai atau hak lintas alur kepulauan.

Pengaturan internasional khususnya bagi penerbangan merupakan perkembangan baru dalam hukum udara yang pengaturannya disatukan dengan hukum laut. Diakuinya kedaulatan Negara kepulauan atas ruang udara di atas perairan kepulauan, menimbulkan konsekuensi pada kewenangan pengaturan serta penegakan kedaulatan dari Negara 
kepulauan atas lintas penerbangan pesawat udara asing dalam wilayah ruang udaranya (Kay Hailbronner : 501).

Indonesia telah meratifikasi UNCLOS 1982 dengan pengiriman instrument of ratification ke Sekretariat PBB pada tanggal 3 Februari 1986, dengan demikian dalam kaitannya dengan status Indonesia sebagai Negara kepulauan, maka Indonesia mempunyai kewenangan menentapkan alur laut kepulauan dan mengatur pelaksanaan lintas penerbangan pesawat udara asing melalui wilayah udara Negara Indonesia. Termasuk di dalamnya adalah penegakan kedaulatan Negara hukum di ruang udara Indonesia. Penegakan kedaulatan negara di ruang udara mencakup pengertian penegakan hukum di udara dilakukan oleh TNI-AU untuk mempertahankan keutuhan wilayah udara nasional, bersamasama dengan segenap komponen kekuatan pertahanan keamanan negara. Penegakan kedaulatan dan hukum di udara dilakukan sesuai dengan kewenangan yang diatur dalam peraturan perundangan, baik dalam tingkat nasional maupun dalam kaitannya dengan ketentuanketentuan hukum internasional, hal ini sejalan dengan maksud yang terdapat dalam Pasal 10 ayat (3) Undang Undang Republik Indonesia Nomor 3 Tahun 2002 tentang Pertahanan Negara, jo. Pasal 10 Undang Undang Republik Indonesia Nomor 34 Tahun 2004 tentang Tentara Nasional Indonesia.

Sebagai implemintasi dari article 53 UNCLOS 1982, akhirnya melalui Pasal 18 dan 19 Undangundang Nomor 6 tahun 1996 tentang Perairan Indonesia (UU No.6 Tahun 1996) jo. Peraturan Pemerintah Nomor 37 Tahun 2002 tentang Hak dan Kewajiban Kapal dan Pesawat Udara Asing Dalam Melaksanakan Hak Lintas Alur Laut Kepulauan Melalui Alur Laut Kepulauan Yang Ditetapkan (PP No.37 Tahun 2002), diatur dan ditetapkanlah alur laut kepulauan Indonesia, yang dapat digunakan untuk lintas pelayaran dan lintas penerbangan kapal dan pesawat udara asing melalui wilayah perairan dan ruang udara Indonesia. Dalam penelitian ini fokus pembahasan pada lintas penerbangan pesawat udara asing melalui wilayah udara Negara kepulauan. Berdasarkan uraian latar belakang permasalahan diatas, maka fokus pembahasan dalam penulisan hukum ini adalah : Pengaturan lintas penerbangan nasional bagi pesawat udara asing yang melintasi Alur Laut Kepulauan Indonesia.

\section{Pembahasan \\ Rute Udara Dalam Kegiatan Penerbangan}

Salah satu fasilitas yang harus tersedia dalam kaitannya dengan kegiatan penerbangan adalah tersedianya rute udara "air route" yang melintasi wilayah suatu negara, sebagaimana ditegaskan dalam Pasal 68 Konvensi Chicago 1944 bahwa:

Each contracting state may, subject to the provisions of this Convention, designate the route to be followed within its territory by any international air service and the airports which any such service may use".

Adapun tujuannya adalah agar pilot dan petugas lalu lintas udara memungkinkan melakukan otomatisasi dalam pengoperasian pesawat udara yang berhubungan dengan pengaturan lalu lintas. Dalam prakek penerbangan, hal ini sangat berguna, yang salah satunya 
adalah untuk mengurangi frekuensi percakapan antara petugas lalu lintas udara dengan penerbang terutama di Bandar Udara yang sedang ramai.

Sehubungan dengan rute udara, Konvensi Chicago 1944 melalui pasal-pasalnya hanya menegaskan penggunaan rute udara yang sudah ditetapkan, seperti yang diatur dalam Pasal 11 yang pada intinya tidak boleh adanya diskriminasi dalam penggunaan rute yang didasarkan pada nasionalitas serta menekankan kepada setiap pesawat untuk mematuhinya. Article 11 Konvensi Chicago 1944 :

Subject to the provisions of this Convention, the laws and regulations of a contracting State relating to the admission to or departure from its territory of aircraft engaged in international air navigation, or to the operation and navigation of such aircraft while within its territory, shall be applied to the aircraft of all contracting States without distinction as to nationality, and shall be complied with by such aircraft upon entering or departing from or while within the territory of that State.

Konsekuensi lain berkaitan dengan penggunaan penetapan dan penggunaan rute adalah :

1) Sebuah rute atau bagian dari sebuah rute di bagian wilayah udara suatu negara, berada di bawah kedaulatan negara yang menetapkan dan memberikan pelayanan lalulintasnya sendiri;

2) Sebuah rute atau bagian dari suatu rute yag terdapat di dalam wilayah udara dibawah kedaulatan negara yang bersangkutan, dapat mendelegadikan tanggung jawab terhadap ketetapan dan penetapan dari pelayanan lalu lintas udara berdasarkan perjanjian kerjasama;

3) Bagian dari sebuah rute terdapat di atas wilayah laut bebas atau wilayah yang tidak berkedaulatan, dimana negara menerima tanggung jawab untuk penentuan dan penetapan dari pelayanan lalu lintas udara.

Undang Undang Nomor 1 Tahun 2009 tentang Penerbangan jo Peraturan Pemerintah Nomor 40 Tahun 1995 tentang Angkutan Udara juga dijelaskan pengertian Rute, sebagai berikut: "rute penerbangan adalah lintasan pesawat udara dari Bandar udara asal kebandar udara tujuan melalui jalur penerbangan yang telah ditetapkan". Pengertian tentang rute sebagaimana disebutkan di atas juga diatur dalam Keputusan Menteri Perhubungan No. KM 11 Tahun 2001 tentang Penyelenggaraan Angkutan Udara. Dalam Keputusan Menteri tersebut dijelaskan bahwa kumpulan rute penerbangan yang merupakan satu kesatuan jaringan pelayanan angkutan udara ada dua yaitu jaringan penerbangan dalam negeri dan jaringan penerbangan luar negeri. Jaringan penerbangan dalam negeri terdiri dari struktur rute utama, rute pengumpan, dan rute perintis. Dengan demikian rute yang dimaksud dalam ketentuan ini adalah rute yang berhubungan dengan penerbangan suatu pesawat udara dari suatu bandara asal ke bandar udara tujuan. Bukan rute yang berhubungan dengan pengaturan lalu lintas udara.

\section{Pengaturan Lintas Penerbangan Dalam UNCLOS 1982}

Kegiatan lintas penerbangan melalui wilayah udara Indonesia yang dimaksud adalah kegiatan lintas penerbangan pesawat udara 
asing dikaitkan dengan berlakunya UNCLOS 1982, yang hal ini merupakan pengaturan baru dalam bidang hukum udara. lintas penerbangan yang dilakukan oleh pesawat udara sipil asing selama ini mengikuti sepenuhnya pengaturan lintas penerbangan sebagaimana di atur dalam Konvensi Chicago 1944 beserta annex-annexnya.

Permasalahan lintas penerbangan yang diperdebatkan oleh di antara negara-negara besar, seperti Amerika Serikat, Uni Soviet (sebelum bubar), Inggris dengan negara-negara yang menamakan dirinya negara kepulauan, seperti Indonesia, Philipina, Fiji, Mauritius bersumber pada konsepsi kepulauan yang perlu mendapat pengakuan dan diterima oleh negara-negara anggota masyarakat internasional. Konsepsi kepulauan merupakan salah satu persoalan dari sekian banyak persoalan yang dibicarakan di dalam Konferensi Hukum Laut PBB III, yang di dalamnya terdapat perbedaan kepentingan.

Dalam bidang hukum laut pada awalnya terdapat dua teori atas penguasaan wilayah laut, yaitu teori Mare leberium wilayah laut merupakan milik semua umat manusia atau atas wilayah laut tidak berlaku kedaulatan; dan Mare clausum, bahwa wilayah laut berada di bawah kekuasaan atau kekaulatan negara. Demikian juga terhadap wilayah ruang udara, pada awalnya berkembang Teori Kebebasan di Udara (the Air freedom theory) bahwa ruang udara sebagai wilayah bebas sesui dengan sifat udara, dan teori kedaulatan di udara ( the air soveregnty theory). Demikian juga atas wilayah laut maupun wilayah ruang udara merupakan wilayah yang sering digunakan sebagai wilayah atau jalur lintas oleh kapal atau pesawat udara asing dari satu wilayah negara yang satu ke wilayah negara lain. Kapal dan pesawat udara sering digunakan oleh negara di kedua wilayah tersebut walaupun berbeda namun sering melakukan aktivitas secara bersama-sama, lebih-lebih bila sarana transportasi tersebut merupakan sarana transportasi militer. Dalam hal ini adanya kapal induk (militer) yang apabila berlayar sampai melintas batas negara sering di atasnya disertai atau dikawal oleh pesawat militer. Sehingga sering dijumpai dalam suatu ketentuan internasional yang mestinya diutamakan mengatur penguasaan atau pemanfaatan wilayah laut, di dalamnya mengatur juga aspekaspek yang mestinya menjadi bagian dari hukum udara. Seperti misalnya dalam Konvensi Jenewa 1958 Tentang Laut teritorial dan Zona tambahan dalam Pasal 2 menyebutkan kedaulatan negara meliputi ruang udara di atas laut teritorial. Pasal 2 Konvensi Jenewa 1958 tentang Laut Bebas dalam mengatur adanya Kebebasan penerbangan di atas Laut Bebas. Prinsip kebebasan terbang di atas laut bebas sebenarnya tidak banyak fedahnya bagi Negara-negara yang berkembang, sebab penerbangan kapal-kapal terbang sipil pada dasarnya telah diatur oleh ICAO. Prinsip kebebasan penerbangan di atas laut bebas hanya banyak artinya bagi penerbangan militer Negara-negara besar-besar. Disinilah terletak suatu ironi yang luar biasa. Dalam mempertahankan kebebasan terbang tersebut bagi keperluan kapal terbang militer. Negara-negara maritim besar yang mempunyai kepentingankepentingan militer secara global sangat mendesakkan kebebasan 
terbang melalui selat-selat yang sempit melalui laut wilayah Negara lain (khususnya negara-negara yang sedang berkembang). Tetapi mereka sendiri mewajibkan kapal-kapal terbang asing yang berada di Laut bebas di sepanjang pantai mereka, yang kadang-kadang jaraknya ratusan mil dari pantai mereka, untuk tunduk kepada control mereka dari darat, sesuai dengan prinsip-prinsip Defence Identivication Zona yang mereka anut. (Hasjim Djalal, 1979 : 37). Lebih lagi bila di cermati pasal-pasal dalam UNCLOS 1982, terdapat sejumlah pasal yang berkaitan dengan hukum udara.

Sehubungan dengan

berlakunya UNCLOS 1982, beberapa ketentuan dalam konvensi tersebut menunjukkan adanya progresive development bagi hukum internasional berkaitan dengan rejim ruang udara yang berdekatan dan diatasnya dan memerlukan penelitian yang mendesak bagi penerapan hukum udara internasional. Pada Sidang Majelis International Civil Aviation Organization (ICAO) yang ke 23 tahun 1980, diputuskan bahwa: "Dewan ICAO akan tetap bekerja untuk mengikuti perkembangan atas Badan-badan yang berbeda dalam PBB dan akan meminta pada Komite Hukum, jika dan apabila diperlukan, mengutamakan mempelajari implikasi dari Konvensi Chicago 1944, Annexannex, dan ketentuan-ketentuan hukum udara internasioal yang lain atas hasil-hasil dari Konvensi Hukum Laut 1982". Kemudian, pada tanggal 1 Desember 1982 Dewan ICAO memutuskan meminta pada Komite Hukum untuk :

a. memasukkan dalam program kerja umum mereka pada bagian “Konvensi Hukum laut 1982 penerapannya bagi Konvensi Chicago 1944, Annex-annex dan Hukum udara internasional" yang lain dan,

b. menetapkan suatu cara untuk mempertimbangkan persoalan tersebut, yaitu implikasi Konvensi Chicago 1944 berikut annex-anneknya atas hasil UNCLOS 1982.

Hukum udara dan hukum laut mempunyai kaitan yang erat, khususnya dalam kaitanya dengan aktivitas kapal dan pesawat udara Negara yang sering menyatu sehingga perhatian Negara-negara dalam konferensi hukum laut PBB III tidak bisa lepas juga dengan persoalan-persoalan hukum udara. Negara-negara besar di dunia, khusunya Amerika Serikat dan Soviet Uni, menjadi prihatin memperhatikan perkembangan hukum laut Internasional pada waktu itu. Jika laut wilayah nanti diakui oleh Konvensi hukum laut menjadi 12 mil, maka banyak dari selat-selat yang selama ini merupakan bagian dari laut bebas (jadi dengan rezim penerbangan yang bebas untuk segala jenis pesawat udara) kini akan tertutup karena akan menjadi wilayah udara Negara bawahnya. Labih lagi atas pesawat udara Negara, menurut Konvensi Chicago 1944, sama sekali tidak mempunyai hak lewat tanpa izin di atas wilayah Negara lain, sebagaimana halnya dengan pesawat udara sipil. Karena itulah Negara-negara besar ini selalu menghendaki agar "perluasan" laut wilayah menjadi 12 mil perlu disertai oleh diterimanya suatu klausula di dalam Konvensi yang menjamin kebebasan terbang melalui selat-selat yang dipakai bagi pelayaran internasional untuk seluruh jenis pesawat udara. Kebebasan terbang melalui "air 
routes di atas sealanes" di atas perairan kepulauan juga merupakan salah satu unsur utama pula yang diminta oleh negara-negara besar untuk dapat mengakui konsepsi kepulauan. Menurut Negara-negara besar sebagian dari laut-laut yang dahulu merupakan laut bebas, dengan rezim penerbangan yang bebas akan menjadi bagian dari wilayah udara negara kepulauan yang bersangkutan. Di samping selalu menekankan pentingnya mempertahankan rezim kebebasan penerbangan melalui selat-selat yang dipakai bagi pelayaran internasional dan melalui "air routes" di atas sealanes perairanperairan kepulauan negara-negara besar itu juga ingin tetap mempertahankan status hukum dari zone ekonomi sebagai laut bebas, antara lain untuk tetap menjamin agar kebebasan terbang di atas zone ekonomi tersebut tidak terganggu. Sebaliknya negara-negara selat dan negara-negara kepulauan tertentu, seperti Indonesia dan Philipina, merasa bahwa Konperensi Hukum Laut tidak wajar membicarakan soal "overflight" ini karena soal ini pada dasarnya adalah masalah hukum udara yang harus diatur oleh ICAO.

Konsep archipelago State tidak mempunyai pengaruh negatif apapun terhadap pelayaran internasional sebagaimana sering di tuduhkan oleh negara-negara maritim yang besar yang mempunyai kepentingankepentingan militer secara global. Kapal-kapal dagang yang memang sangat perlu bagi perdagangan internasional tetap dapat berlayar sebagaimana biasa melalui routeroute pelayaran yang secara tradisional telah mereka pergunakan melalui perairan nusantara. Kesulitan timbul karena negara-negara maritim yang besar yang mempunyai kepentingan kepentingan militer secara global menginginkan diterimanya rezim pelayaran yang tersendiri dan yang sebebas mungkin bagi kapal-kapal perang dan kapal-kapal selam serta kapal-kapal terbang militer mereka melalui sealanes di dalam perairan nusantara, tanpa notifikasi kepada negara nusantara ataupun tanpa kewajiban untuk berlayar di atas permukaan air bagi kapal-kapal selam mereka, ataupun tanpa kewajiban melaporkan diri kepada kontrol di darat bagi kapal-kapal terbang mereka. Jika keinginan negara-negara maritime besar ini diterima, dikhawatirkan kapalkapal selam tersebut akan dapat berlayar di bawah air selama beberapa jam ataupun beberapa hari sewaktu "melintasi" perairan Indonesia (siapa tahu bahwa mereka tidak hanya "melintasi" dan tidak melakukan kegiatan-kegiatan lainnya sewaktu mereka transit di bawah air, apalagi karena kemampuan negara-negara archipelago yang umumnya masih lemah dalam soal deteksi). Kapalkapal perang mereka, baik kapal kapal perang konvensionil maupun kapal-kapal perang yang digerakkan dengan tenaga nuklir atau yang membawa senjata-senjata nuklir, akan dapat berlayar melintasi perairan Indonesia melalui sealanes dengan bebas. Hal ini dikhawatirkan dapat menyukarkan Indonesia mengambil tindakan-tindakan precaution atau preventif untuk memelihara keamanannya, kestabilan politiknya, serta kelestarian lingkungan lautnya jika terjadi kecelakaan, baik kecelakaan nuklir maupun kecelakaan lainnya yang dapat menimbulkan pencemaran laut. 
Rezim pelayaran sebagai mana yang diinginkan oleh Negaranegara maritime besar tersebut akan dapat menjadikan laut Indonesia sebagai tempat pertemuan antara kekuatan-kekuatan maritim, dan siapa yang dapat mengatakatakan bahwa perbuatan antar angkatanangkatan perang asing di perairan Indonesia, tanpa Indonesia sama sekali mengetahuinya, tidak akan berkembang menjadi konfontrasi antara mereka, dan karena itu, akan dapat membawa gangguan bagi keamanan dan kestabilan Indonesia, dan karena itu juga akan membawa gangguan terhadap keamanan dan kestabilan politik Negara-negara di wilayah ini. Jelas kiranya bahwa rezim pelayaran melalui sealanes seperti yang diinginkan oleh negara-negara maritim tersebut sukar dapat diterima oleh Indonesia. Karena itu, suatu rezim pelayaran yang seimbang, yaitu yang dapat menjamin keamanan, keselamatan dan kestabilan Indonesia tanpa menimbulkan hambatan-hambatan yang tidak wajar bagi kapl-kapal yang lewat harus merupakan inti dari regime "archipelagic sealanes passage" yang sedang dikembangkan itu. Kiranya rezim semacam ini yang pada akhirnya disepakati dalam Konvensi Hukum Laut PBB III-1982.

\section{Implementasi Pasal 53 UNCLOS 1982 di Indonesia Dalam Penetapan Alur Laut Kepulauan Indonesia}

Dengan telah diratifikasi Konvensi Hukum Laut 1982, maka status negara kepulauan, telah mendapatkan pengakuan dan pengaturan secara internasional. Keberadaan negara kepulauan membawa konsekuensi pada tersedianya alur laut kepulauan dan rute penerbangan melalui wilayah udara negara kepuluan. Alur laut kepulauan dan rute penerbangan dimaksud tentunya bukan alur laut dan rute penerbangan yang ada sebagai alur laut pelayaran dan rute penerbangan sipil, namun rute yang dibangun sebagai hasil kompromi antara kepentingan negara maju dengan negara kepulauan. Dalam rangka mengakomodasikan kepentingan pelayaran dan penerbangan internasional negara kepulauan may designate alur laut dan rute penerbangan di atasnya.

Beberapa negara peserta konferensi tersebut terdapat perbedaan pandangan. Perbedaan pandangan itu antara lain pelayaran melalui Alur Laut kepulauan itu merupakan "hak" atau "kebebasan". Negara Maritim Besar, menuntut adanya innocent passage melalui alur laut adalah kebebasan, mengingat wilayah itu dulunya merupakan wilayah laut bebas. Sedangkan, negara kepulauan sendiri bersedia mengakui innocent passage melalui lalur laut kepulauan sebagai "hak" bagi pelayaran internasinal. Demikian juga, negara kepulauan (khususnya Indonesia dan Philipina) tidak dapat menerima rezim free transit melalui alur laut. Sebab, bila berlaku free transit nantinya akan merugikan negara kepulauan itu sendiri

Setelah melalui perdebatan yang cukup panjang dan memakan waktu yang lama, akhirnya berhasil disepakati tentang keberadaan Alur Laut Kepulauan dan rute Penerbangan di atasnya, sebagaimana secara lengkap dirumuskan dalam Article 53 UNCLOS 1982.

Pada tanggal 19 Mei 1998, dalam Sidang ke-69 Komisi Keselamatan Pelayaran (Maritime Safety Committee $=$ MSC), Organsasi Maritim Internasional (International 
Maritime Organization $=I M O)$ telah menyetujui usul Pemerintah Indonesia tentang Alur-Alur Laut Kepulauan Indonesia (ALKI) (Etty R Agoes, 2004 : 353). Penetapan ALKI menyangkut pertahanan dan keamanan negara. penetapan alur lintas laut kepulauan harus merupakan sumbangan bangsa Indonesia dalam rangka mewujudkan ketertiban dunia. Oleh karenanya di samping harus mempertimbangkan kepentingan masyarakat internasional, hendaknya tidak sampai mengorbankan kepentingan bangsa dan negara Indonesia. Hasil pengkajian dari Forum Strategi TNIAL diusulkan alur-laur laut Kepulauan, yakni meliputi :

Alur Laut Kepulauan I, yang meliputi Selat Lombok - Selat Makasar - laut Sulawesi.

Alur Laut Kepulauan II, yang meliputi Selat Sunda - Laut Jawa, kemudian ada yang ke selat Malaka dan yang lain ke arah - Selat Karimata - Laut Nutuna - Laut Cina Selatan.

Alur Laut Kepulauan III, meliputi :

- Selat Ombai, Selat Water, Laut Banda (barat P. Buru), Laut Seram (Timur P. Monggopoli), Laut maluku, Laut Pasifik.

- Laut Timor, Selat Leti, Laut Banda (Barat P. Buru), Laut Seram (Timur P. Monggoli), Laut Maluku, Laut Pasifik.

- Laut Arafuru, Laut Banda (Barat P. Buru), Laut Seram (Timur P. Monggoli), Laut Maluku, Laut Pasifik (Hasil Seminar Forum Strategi TNI-AU, tanggal $12-27$ Agustus 1991).

- Pada waktu itu ALKI hasil usulan dari Forum Strategi TNI-AL terus dievaluasi, untuk menekan dampak-dampak negatif yang mungkin timbul dalam pelaksanaannya. Konsep dari
Forum Strategi TNI-AL yang telah dimantapkan dan kemudian digunakan sebagai bahan konsultasi secara informal, yaitu yang pertama dengan Amerika Serikat, Australia, Jepang, dan Inggris Setelah konsultasi dengan beberapa negara dan persiapan dianggap cukup, akhirnya secara resmi Indonesia menyampaikan usul penetapan ALKI kepada IMO, pada sidang MSC-67 yang diadakan antara tanggal 2-6 Desember 1996. melalui beberapa persidangan dan revisi berdasarkan masukan dari peserta sidang MSC, akhirnya usul Indonesia tentang penetapan aluralur laut kepulauan tersebut diadopsi oleh Sidang pleno MSC-69 pada tanggal 19 Mei 1998. Dalam Resolusi tersebut juga ditegaskan bahwa Pemerintah Indonesia dalam menetapkan alur laut kepulauan supaya konsisiten dengan ketentuan yang terdapat dalam UNCLOS. Pengaturan pelayaran dan penerbangan melalui alur laut kepulauan baru dapat dipenuhi empat tahun kemudian, yaitu dengan diumumkannya Peraturan Pemerintah Nomor 37 Tahun 2002 tentang Hak dan Kewajiban Kapal dan Pesawat Udara Asing dalam Melaksanakan Lintas Alur Laut Kepulauan Melalui Alur Laut Kepulauan, yang diumumkan pada tanggal 28 Juni 2002. Peraturan ini berlaku sejak saat ditetapkan, namun kapal dan pesawat udara asing baru dapat menggunaan ALKI enam bulan kemudian (PP nomor 37 tahun 2002).

Penetapan rute penerbangan yang demikian akan ditetapkan di atas dan sejajar alur laut kepulauan. Hal ini didasarkan pada salah satu pertimbangan historis, bahwa adanya rute penerbangan di atas alur laut kepulauan yaitu untuk memenuhi kebutuhan pesawat- 
pesawat militer (pesawat udara negara) yang melakukan pengawalan atas kapal-kapal militernya.

Hak dan Kewajiban Negara Kepualauan Terkait Pelaksanaan Hak Lintas Penerbangan Melalui Alur Laut Kepulauan Dalam Lintas Penerbangan Khusus Wilayah Udara Indonesia

Dengan adanya pelaksanaan lintas penerbangan melalui rute udara di atas alur laut kepulauan, Pemerintah Indonesia mempunyai hak atau kekuasaan antara lain; pertama, pemerintah Indonesia berhak untuk menetapkan rute penerbangan di atas alur laut kepulauan, setelah merperhatikan aspek keselamatan penerbangan dan keamanan negara. Sebagai negara berdaulat, negara Indonesia yang paling berhak mengatur penggunaan atau pemanfaatan wilayah ruang udaranya. Kedua, mempunyai hak atau kekuasaan untuk memaksa pesawat udara sewaktu melakukan lintas penerbangan untuk menghormati kedaulatan, keutuhan wilayah, integritas politik negara kepulauan dan memaksa pesawat udara untuk mentaati peraturan perundangan yang dikeluarkan oleh negara kepulauan (Pasal 53 ayat (1), ayat (6) Pasal 42 ayat (4) UNCLOS 1982). Pelaksanaan hak atau kekuasaan tersebut disesuaikan dengan jenis pesawat udara yang melakukan pelanggaran jalur. Sebagaimana di uraikan di atas, bahwa yang melakukan pelanggaran tersebut adalah pesawat udara sipil, maka tidakan yang diambil adalah memaksa pesawat udara tersebut untuk melakukan pendaratan pada bandar udara terdekat untuk kemudian diadakan penyelidikan. Sedangkan bila yang melakukan pelanggaran adalah pesawat udara negara atau militer, maka tidakan yang diambil adalah mengusir pesawat udara tersebut untuk meninggalkan wilayah udara Indonesia. Bahkan bila sampai tidak mau meninggalkan wilayah Indonesia maka, atas pesawat udara tersebut dapat dilakukan tindakan kekerasan senjata.

Kemudian sehubungan dengan hak lintas alur laut kepulauan bagi pesawat udara asing melalui wilayah udara negara kepulauan, khususnya melalui rute penerbangan di atas alur laut kepulauan, maka kewajiban negara Indonesia antara lain (pasal 53 ayat (1), (3) dan (10) UNCLOS 1982 :

a) Menetapkan rute penerbangan di atas alur laut kepulauan, bila tidak ingin terjadi lintas penerbangan melalui rute rute yang biasa digunakan untuk navigasi udara.

b) Menjamin kelancaran lintas penerbangan pesawat udara asing melalui rute penerbangan yang bersangkutan.

c) Menetapkan dalam peta-peta tentang posisi rute penerbangan di atas alur laut kepulauan dan mengumumkan sebagaimana mestinya.

d) Menjaga keselamatan penerbangan dan memberikan pertolongan terhadap pesawat udara yang dalam keadaan bahaya.

Penetapan rute penerbangan di pandang sebagai "kewajiban", apabila hal ini dihadapkan pada:

(1). Konsekuensi ratifikasi atas suatu perjanjian maka dapat dikatakan sebagai kewajiban negara yang telah meratifikasi suatu perjanjian. Khususnya dalam hal ini merupakan 
kewajiban negara kepulauan Indonesia untuk menetapkan rute penerbangan melalui wilayah udara perairan kepulauan, sekalipun kewajiban dalam kasus ini bisa dihindari.

Dengan pertimbangan, pertama, Perumusan Pasal $53 \quad$ (1) menggunakan kata "may" (dapat), yang bisa diartikan sebagai pilihan, yaitu menentukan dan menetapkan rute penerbangan yang demikian atau tidak. Kedua, bila tidak maka negara kepuluan akan membiarkan pelaksanaan hak lintas penerbangan melalui rute penerbangan pada wilayah udara negara kepulauan dilaksanakan melalui rute yang biasa digunakan untuk penerbangan internasioal.

(2). Adanya hak lintas penerbangan melalui rute udara di atas alur laut kepulauan bagi pesawat udara asing, ini berarti merupakan kewajiban negara kepulauan untuk menetapkan rute penerbangan yang cocok. Dalam hubungan hukum, apa yang menjadi hak seseorang maka akan menjadi kewajiban bagi pihak lain. Pesawat udara asing mempunyai hak lintas penerbangan yang demikian. Jadi pada dasarnya kewajiban negara kepulauan, termasuk Indonesia untuk menyediakan rute penerbangan melalui wilayah udara negara kepulauan, sebagai pelaksanaan hak melakukan lintas penerbangan secara cepat, turus menerus, dan tidak terhalang.

Terkait dengan lintas penerbangan khusus dalam UNCLOS 1982 tidak secara tegas mengatur lintas penerbangan yang demikian. Namun, pada kenyataannya lintas penerbangan khusus ini muncul dalam praktek hubungan antara Indonesia dan Malaysia, yang didasarkan pada ketentuan dalam Pasal 47 ayat 6, yang menyatakan bahwa :

"apabila suatu bagian perairan kepulauan suatu Negara Kepulauan, terletak di antara dua bagian suatu negara tetangga yang langsung berdampingan, hak-hak yang ada dan kepentingankepentingan sah lainnya yang dilaksanakan perairan demikian, serta segala hak yang dietapkan dalam perjanjian antara negaranegara tersebut akan tetap berlaku dan harus dihormati".

Disebut sebagai lintas penerbangan khusus, karena lintas yang demikian adalah :

a). bukan merupakan rezim lintas damai. Karena, rezim lintas damai di ruang udara tidak diakui dalam hukum udara.

b). bukan merupakan lintas transit. Karena, dilaksanakan bukan di atas selat yang digunakan untuk pelayaran internasional.

c). bukan termasuk lintas penerbangan di atas alur laut kepulauan. Karena, lintas penerbangan yang demikian tidak dilakukan di atas alur laut kepulauan, melainkan dilakukan melalui koridordoridor yang ditentukan oleh perjanjian bilateral (Atje Misbach Muhjiddin, 1993 : 208-209).

Dalam penggunaan wilayah udara Indonsesia, maka Malaysia juga mempunyai hak yaitu, hak-hak Malaysia di wilayah ruang udara nasional Indonesia adalah hak akses dan komunikasi pesawat udara 
negara dan pesawat udara sipil. Terkait dengan hal terrsebut dalam pelaksanaan hak-hak tersebut antara Republik Indonesia dan Malaysia wajib mengadakan konsultasi dengan maksud untuk mencapai pengaturan yang mungkin bagi lintas penerbangan dan manuver pesawat udara.

Berdasarkan adanya lintas penerbangan khusus yang terjadi dalam hubungan Indonesia dengan Malaysia, dapat disimpulkan bahwa lintas penerbangan melalui wilayah ruang udara negara kepulauan Indonesia dapat dibedakan antara Hak Lintas, yaitu keberadaan dan pengaturannya berdasarkan Pasal 5 dan 6 Konvensi Chicago 1944, Hak Lintas Alur Laut Kepulauan, termasuk di dalamnya adalah hak lintas Transit dan Hak Lintas Khusus yang lahir berdasarkan praktek hubungan antara IndonesiaMalaysia, yang didasarkan pada ketentuan dalam Pasal 47 ayat 6 UNCLOS 1982. Semua hak lintas penerbangan tersebut pada hakikatnya tunduk pada ketentuanketentuan hukum udara internasional dan hukum udara nasional Indonesia. Atas beberapa jenis lintas penerbangan tersebut yang masih memerlukan penyempurnaan dalam pengaturan lebih lanjut, baik dalam tingkat internasional maupun tingkat nasional.

\section{Simpulan}

Dengan adanya pelaksanaan lintas penerbangan melalui rute udara di atas alur laut kepulauan, Pemerintah Indonesia mempunyai untuk menetapkan rute penerbangan di atas alur laut kepulauan, setelah merperhatikan aspek keselamatan penerbangan dan keamanan negaranya. Sehubungan dengan adanya hak lintas alur laut kepulauan bagi pesawat udara asing melalui wilayah udara negara kepulauan, khususnya melalui rute penerbangan di atas alur laut kepulauan, maka kewajiban negara Indonesia seperti halnya tertuang dalam pasal 53 ayat (1), UNCLOS 1982.

\section{Saran}

Dalam kegiatan lintas penerbangan masih memerlukan penyempurnaan dalam pengaturan lebih lanjut, baik dalam tingkat internasional maupun tingkat nasional. Hendaknya Pemerintah Indonesia lebih serius dalam usaha pengamanan wilayah udara Indonesia terkait kegiatan penerbangan terutama penerbangan bagi pesawat udara asing yang melintas di ALKI.

\section{Daftar Pustaka}

Djalal Hasjim, Perjuangan Indonesia Di Bidang Hukum Laut, 1979, Percetakan Ekonomi, Bandung

E Saefullah,, Tinjauan singkat Atas Berbagai Perjanjian Internasional di Bidang Hukum Udara, 1990, Lisan, Bandung

Misbach Atje Muhdjidin, 1993, Status Hukum Perairan Kepualauan Indonesia dan Hak Lintas Kapal Asing, Alumni, Bandung

Peter Mahmud Marzuki, 2006, Penelitian Hukum,Cetakan Kedua, Prenada Media Jurnal :

R. Agoes, Etty, 2004, Praktik NegaraNegara atas Konsepsi Negara Kepulauan, dalam Jurnal Hukum Internasional, Fakultas Hukum UI, Jakarta Konvensi Internasional dan Peraturan Perundangundnagan :

Convention on International Civil Aviation 1944 
United Nation Convention On The Law Of The Sea 1982

Convention Relating To Aerial

Navigation Paris 1919

Undang-Undang Nomor 1 Tahun

2009 tentang Penerbangan http://ibrary.arcticportal.org/1580/1/19 19_Paris_conevention.pdf.

http://www.mcgill.ca/files/iasl/ch icago1944a.pdf, diakses 15Oktober 2018 